\title{
RADIOCARBON AND DENDROCHRONOLOGICAL DATES OF THE CORDED WARE CULTURE
}

\author{
Piotr Włodarczak \\ Instytut Archeologii i Etnologii PAN, ul. Sławkowska 17, 31-016 Kraków, Poland. Email: wlodarczak.piotr@gmail.com.
}

\begin{abstract}
This paper presents and discusses radiocarbon dates of the Corded Ware culture (CWC) from different regions of Europe (mainly from southern and central Germany and southern and central Poland). The main questions addressed are the controversial significance of particular results, the incompatibility of the obtained date sequences, and the "imprecision of the method." There is clearly the problem of hundreds of dates from different laboratories and performed in different years. A slight difference in the results leads to an "elongated" chronology and acceptance of a model with synchronicity of many cultural groups. The proposed verification of the ${ }^{14} \mathrm{C}$ chronology is connected with both the dendrochronological method and the comparison of dating sequences obtained from particular regions. At present, the most reliable dating scheme for the Corded Ware culture is the one based on the dendrochronological dates of settlements on Swiss lakes; therefore, the scheme must constitute a reference point for ${ }^{14} \mathrm{C}$ analyses conducted for other regions. Due to the typological diversity of materials, however, not every situation allows for this approach. Thus, many ${ }^{14} \mathrm{C}$ grave dates, particularly the results referring to the late CWC phase (after $\sim 2400 \mathrm{BC}$ ), remain controversial.
\end{abstract}

\section{INTRODUCTION}

The Corded Ware culture radiocarbon dates are numerous and come from many regions in central, northern, and eastern Europe. Generally, they refer to the 3rd millennium BC. Although their number gradually increases every year, there is only 1 up-to-date discussion of the matter, summarized in the work by Furholt (2003), concerning the issue of absolute dating of particular regional groups of the Corded Ware culture. The work quoted here is an example of an attitude towards ${ }^{14} \mathrm{C}$ method, assuming the possibility of establishing a detailed chronological division within the culture. ${ }^{14} \mathrm{C}$ dates may be helpful in building a dispersion pattern of certain cultural features determining the substance of the Corded Ware culture (CWC), e.g. pottery (e.g. Furholt 2004). Reconstructions using ${ }^{14} \mathrm{C}$ dates to construct a chronological division of the $\mathrm{CWC}$ have already been presented at the time when non-calibrated markings were used (e.g. Lanting and van der Waals 1976; Breunig 1987). There are other reconstructions, however, which do not share such a great optimism. They raise the issue of the controversial significance of particular results, the incompatibility of the obtained date sequences, and ultimately the "imprecision of the method." Undoubtedly, verification of the method, which is still employed too rarely, is a helpful means for solving the problems encountered. Examples of such a verification are presented below. They are connected with both the dendrochronological method and the comparison of dating sequences obtained from particular regions.

The correctness of chronological models based on ${ }^{14} \mathrm{C}$ dating can presently be verified only by means of dendrochronology. This is possible only for the finds from Switzerland and partly for those from southern Germany. While comparing the results obtained via the 2 methods, there is a danger of making a simple generalization of a cultural model from 1 region onto all the remaining ones. Another obvious drawback is the homogeneity of the dated materials from palafitte settlements, particularly those strongly affected by climatic changes. As a result, a chronological sequence based on dendrochronology consists of the accumulated dates and occurring in between, a sometimes quite long hiatus. ${ }^{14} \mathrm{C}$ dates coming from different regions, different sites, and different environments can represent a more complete chronological spectrum. These differences between ${ }^{14} \mathrm{C}$ and dendrochronological dating must be taken into account. However, there are also reasons why it is worth comparing the 2 methods. The first, and by far the most important, one is the fact that dendrochronology is much more precise. Apart from that, the above-mentioned territory of Switzerland and southern

(C) 2009 by the Arizona Board of Regents on behalf of the University of Arizona

Proceedings of the 5th International ${ }^{14} \mathrm{C}$ and Archaeology Symposium, edited by Irka Hajdas et al.

RADIOCARBON, Vol 51, Nr 2, 2009, p 737-749 
Germany belongs to a wider circle of central and northern European territories, whose general model of cultural development has been established via the typological methods of relative chronology (e.g. Strahm 1992). Before dendrochronology was employed, the chronological models from territories adjacent to the Alps did not differ from the suggestions for other regions, and very often they simply corresponded to them (e.g. Strahm 1971). Since the image obtained for Switzerland by means of dendrochronology in many places led to a revision of the prior reconstructions based on comparative typology and ${ }^{14} \mathrm{C}$ dating, an important problem emerges. Should we also expect a similar revision for other territories of Europe when we apply a new, more precise dating method?

\section{DENDROCHRONOLOGICAL DATING OF THE CORDED WARE SETTLEMENT IN EASTERN SWITZERLAND}

The chronology of all the Corded Ware culture (CWC) phases based on dendrochronology has been completed only for the territory of Switzerland (e.g. Gross-Klee and Eberli 1997; Hardmeyer 1993; Winiger 1993; Włodarczak 2007). The data from Germany are still insufficient and can only play an auxiliary role. As a model territory for our analysis, the region of Zurich was chosen, namely the palafittes on the lake of Zurich, the Greifensee, and the Pfäffikersee (Włodarczak 2007). The data from other parts of Switzerland, and particularly from the Three Lakes region in western Switzerland, confirm the results obtained for the region of Zurich. The latter territory was singled out not only because of a large number of dendrochronological dates, but also because of the clarity of the stratigraphic layers and the abundance of the finds, allowing us to construct the most complete typological and chronological sequence of cultural changes. This model is based on the excavations conducted in Zurich, Kanalisationssanierung and Zurich, Mozartstrasse (Bleuer et al. 1993; Gerber et al. 1994; Gross et al. 1987; Hardmeyer 1993; Schibler et al. 1997). It was there that the groups of layers dated, respectively, to the early and middle phases of the $\mathrm{CWC}$ were documented. Due to the dynamics of erosion processes occurring in the 26th and 25th century BC, no equally abundant finds from the younger CWC phase have been discovered. At present, the oldest dated site is Zurich, Wollishofen "Strandbad" (Hardmeyer and Ruoff 1983; de Capitani 1993). A short series of dendrochronological dates, insufficient for a more precise dating, shows that those finds ought to be dated to before $2725 \mathrm{BC}$. However, there is no convincing evidence of the occurrence of CWC characteristics as early as the first half of the 28th century BC; on the other hand, the youngest date of a cutdown tree from the region of Zurich, coming from Wädenswil, Vorder Au, is 2426 BC (Eberschweiler 1999:48). A little younger dendrochronological date (2418 BC) comes from Ludwigshafen, Seehalde in the region of Lake Constance (Schlichtherle 1991:66-7). Therefore, the period of development of the CWC falls between $~ 350-300$ yr (maximum about 2750-2400 BC). It must be emphasized here that the Swiss finds generally correspond to all the main stages in the development of the CWC in other regions of Europe. This has been repeatedly discussed by the archaeologists dealing with the typological analysis of the finds, particularly by Strahm $(1971,1992)$. The decline of the CWC settlement in Switzerland is clearly marked by the disappearance of settlements on the lakes and the appearance of the Bell Beaker culture. Another important characteristic of the late Neolithic in Switzerland is that the image of the cultural phenomena in the region of Zurich differs from that of the Auvernier-Cordé group in western Switzerland. On the former territory, there is clearly a time gap between the oldest dates of the CWC and the chronology of the hitherto known assemblages of the older culture group. That is why the stylistic and typological differences between the CWC finds and those of the Horgen culture are so clearly marked. On the other hand, in western Switzerland there is a problem with drawing a clear boundary in the series of dendrochronological dates, and determining precisely the beginning of the Auvernier-Cordé phase. It can be seen, for example, in the sites in Saint-Blaise, Bains-des-Dames (Michel 2002), Delley-Portalban II (Ram- 
seyer 1988), and in Yverdon-les-Bains, Avenue des Sports (Wolf 1993). As a result, we observe the appearance of new CWC characteristics in the finds of the Lüscherz group. The regions of Zurich and of the Three Lakes, therefore, represent 2 models of relations between the finds of the older and younger culture units, and the observed differences directly result from the conditions created by the obtained absolute chronology dates. These 2 kinds of relations between the culture units can be treated as models, then we can try to relate them to the finds dated by via ${ }^{14} \mathrm{C}$. However, in the case of individual central European regions, we cannot with certainty evaluate with which of these 2 models we are dealing. Assuming that an accurate time specification for the currently known assemblages of certain cultures was determined, would we obtain an image of time continuity ("overlapping") or would it be a sequence of separate time episodes with groups of dates?

\section{RADIOCARBON DATING OF THE CORDED WARE ASSEMBLAGES IN CENTRAL EUROPE}

In comparison to Switzerland, the situation is different for other territories dated by ${ }^{14} \mathrm{C}$ (Figure 1), as previously observed (e.g. Müller 1999b:84, Abb. 6). The chronological models reconstructed for those territories are characterized by a longer period of the CWC's existence and by the synchronicity of various cultural phenomena. The beginnings of the CWC settlement are usually dated to 2900-2750 BC, thus a little earlier than in Switzerland. There are even some reconstructions that point to even earlier origins, at about 3050-3000 BC. Estimates of the CWC decline vary even more widely. Its decline is dated, depending on the territory, to about 2400-2000 BC. Moreover, it is often assumed that there were other groups coexisiting with the $\mathrm{CWC}$, including the Globular Amphorae culture (GAC), the late phase of the Funnel Beaker culture (TRB), the Bell Beaker culture (BBC), and the Únetice culture (e.g. Müller 1999a). The most important question is this: Does the reconstruction of the chronological model differ so much from that of the territory dated via dendrochronology because a different dating method is employed? Or does it merely reflect a different course of development for the cultural processes of territories adjacent to the Alps than for other European territories? A critical analysis of the ${ }^{14} \mathrm{C}$ dates does not solve this problem, but it allows us to look at it in a different way.

In order to illustrate the problems associated with the employment of the ${ }^{14} \mathrm{C}$ method, some long series of dates from CWC graves have been chosen, with samples being collected in well-established contexts. These are mostly the results from central Germany, southern Germany (Taubertal), southeastern Poland (Little Poland), and central Poland (Kujavia). Predominantly, they are the dates of bones from human burials. They were dated in recent years and in several laboratories. The most significant results from the above-mentioned territories can then be compared with the dating results from the Netherlands (Lanting and van der Plicht 1999/2000) and Denmark (Hübner 2005). Relatively numerous dates from the latter territories, however, are often obtained from samples that were not collected in well-established contexts, and they are of a worse quality (many are results obtained many years ago, characterized by large standard errors).

Many archaeological studies strive for precision at any cost, the scale of which is simply impossible to achieve. The basic difficulty while attempting to date the individual phases of the CWC is connected with the limitations of the method itself, particularly with the character of the calibration curve. For the late Neolithic, the subject of this paper, there are 2 particularly important plateaus of the calibration curve, at 2880-2580 and 2470-2200 BC (Figure 2; Müller 1999a:32; Raetzel-Fabian 2000:129-33; Furholt 2003:15-8). The beginnings of the CWC settlement in most regions can be dated to the period of time marked by the first plateau. If, as in the beginning of the CWC development, a more precise date for the time brackets $2900-2750 \mathrm{BC}$ is provided by some archaeological models, it does not follow directly from analyzing ${ }^{14} \mathrm{C}$ dates. It is always a suggestion of an archae- 


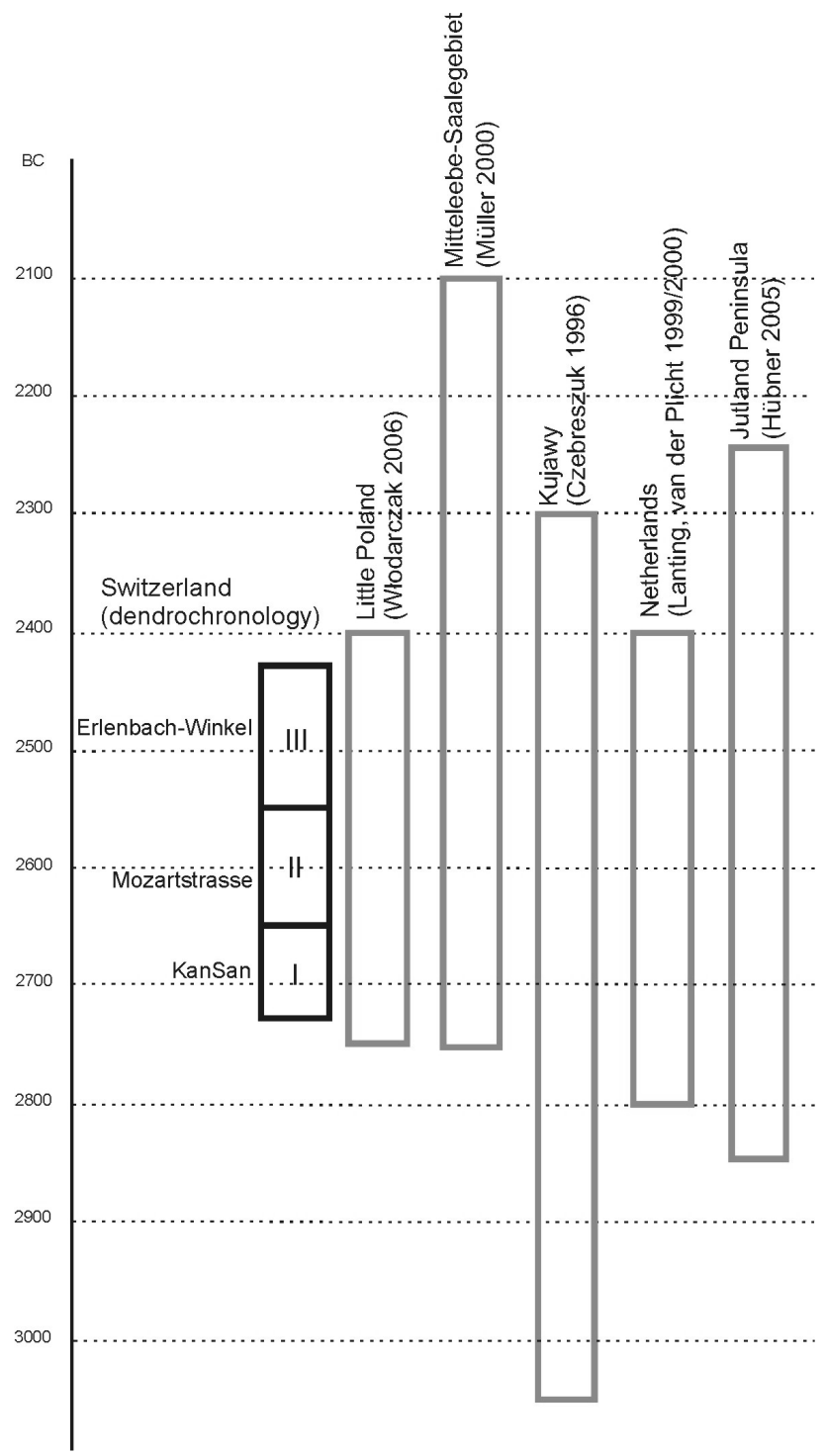

Figure 1 Comparison of the chronology of Corded Ware culture in the selected regions of Europe established on the basis of the dendrochronological and ${ }^{14} \mathrm{C}$ method.

ologist, who is relying on other, additional premises. The difficulty connected with the other plateau, and with the decline of the CWC settlement that falls on these time brackets, is similar. The choice of a particular date from 2470-2200 BC is linked with the chronological relation of the CWC to the Bell Beaker culture. The plateau on the curve makes it difficult to suggest an objective reconstruction, and again an archaeological interpretation is more important, assuming either the synchronicity or sequentiality of cultural changes.

The next problem is that of the quality of ${ }^{14} \mathrm{C}$ dates. There is an unquestionable necessity to analyze the context of a collected sample, and it is automatically assumed by a number of recent works. 


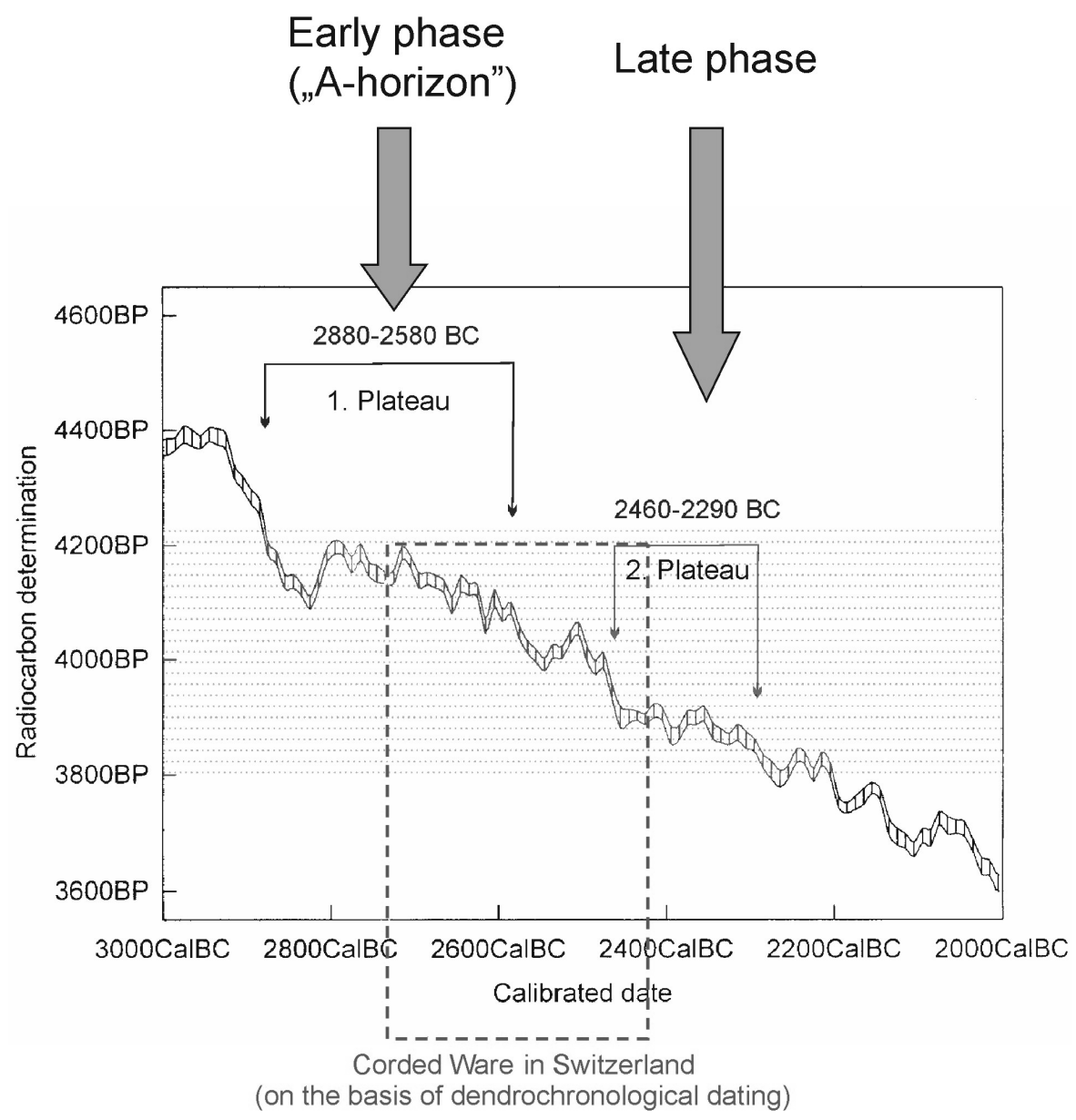

Figure 2 Fragment of calibration curve with selected 2 plateaus significant for the dating of the beginning and the end of the Corded Ware culture.

However, critical evaluation of the analyses of absolute chronology that are currently available leads to a variety of perspectives on the problems of chronology. The authors of particular models approach the available sources differently. For example, we can cite a series of dates for the CWC graves from the Netherlands. Depending on either the acceptance or disregard of the samples that were collected in an ambiguous context, either a very early date of the CWC beginnings or a similar date to that on the adjacent territories is suggested (Furholt 2003; Lanting and van der Plicht 1999/ 2000).

In my opinion, currently the most important problem is the interpretation of differences between individual dates of identical or similar finds, with the samples having been collected in a well-established context. Obviously, the differences caused by natural conditions are also included here, for instance, the so-called reservoir effect (e.g. van der Plicht et al. 2006). However, these problems have not yet been discussed, while the finds linked with the CWC are being analyzed, and this makes it difficult to take them into consideration. ${ }^{1}$ Nevertheless, even an analysis of the existing dates alone leads to a few interesting conclusions.

${ }^{1}$ The importance of this factor has only occasionally been stressed (e.g. Furholt 2003:19-20). 


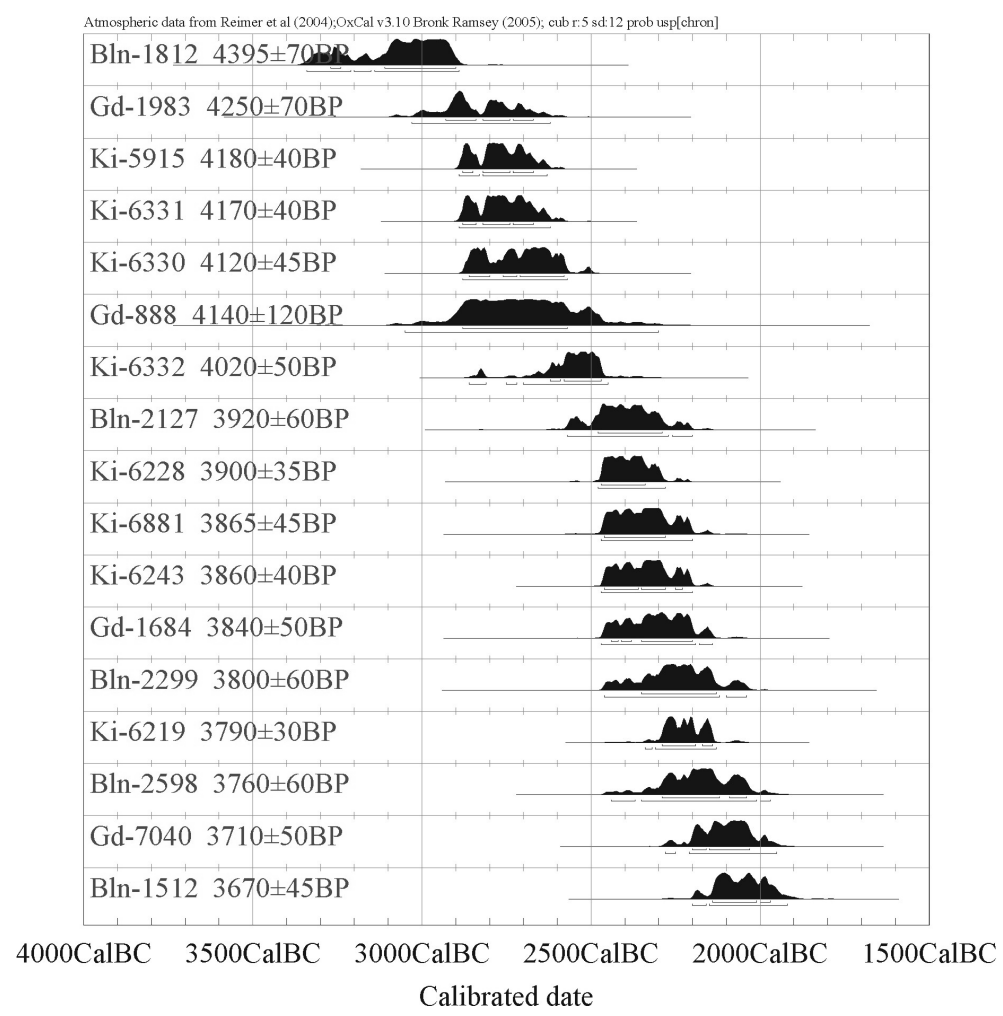

Figure $3{ }^{14} \mathrm{C}$ dates of the Corded Ware culture from Kujavia (central Poland)

For the CWC date series, due to the dominance of burial finds, the dates from individual graves are compared with each other. These dates are therefore more independent from each other than a series from settlement sites. It is not usually possible to mechanically reject the extreme results, differing from the other results with regard to their measurement value. As a consequence, an exceptionally great significance is then often attached to individual results. Characteristically, there are some slightly older or younger dates than the clear majority of the remaining dates from a particular region, and even though, these different-than-the-rest cases occur individually, they are still regarded as very significant. As an example, we can cite 1 date from a CWC grave in Krusza Zamkowa in Kujavia (central Poland) that is clearly older than the remaining dates (Figure 3; Kośko 1992:90). In many studies, this date is regarded as evidence of a very early chronology for the CWC in that territory, pointing to 3270-2900 BC. The next oldest dates from central Poland fall within 2880-2580 BC (Czebreszuk and Szmyt 2001:185-9, Table 1). In the case of archaeological interpretations, very often we lack any objective premises allowing us to disregard such a different date during reconstruction. However, how risky it might be to take into account a single date is shown by the finds that are dated twice. I will cite here 2 examples discussed in the literature. The first one concerns grave 3 in Zielona (Włodarczak 2004:124, Figure 52). There were 2 dates of bones from a human burial performed for (Figure 4; Ki-7949: $4310 \pm 70$ BP and Poz-9585: $3955 \pm 35$ BP). The first date was very early, and that date was used elsewhere as evidence for a very early chronology of the local group of the CWC and the appearance of the catacomb graves in Little Poland as early as the turn of the 4th to 3rd millennium BC. Meanwhile, the second date does not differ from the majority of other dates for CWC graves in southeastern Poland. The second example are the dates 


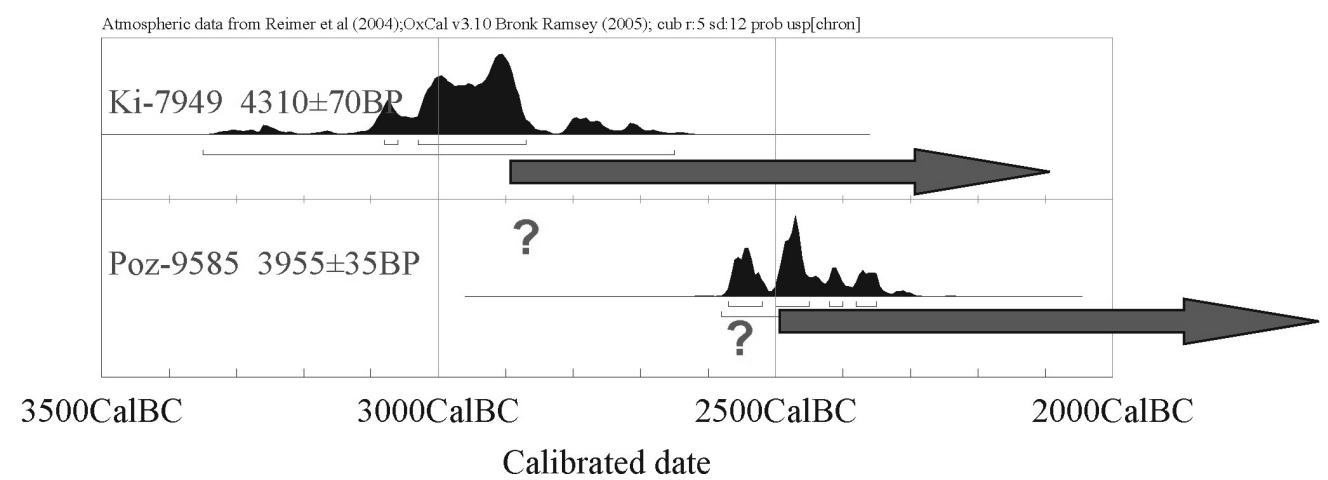

Figure 4 Two ${ }^{14} \mathrm{C}$ dates from grave 3 in Zielona (Little Poland upland) illustrating problems with the dating of phases in the case of catacomb graves in southeastern Poland.

obtained for a grave of the Mansfeld group in Dornburg (Peschel 1963; Furholt 2003:47). The older date (Bln-533: $4065 \pm 80 \mathrm{BP}$; sample material: fragment of oak log from grave coffin) suggests that the Mansfeld group should be dated to the older or middle phase of the CWC. On the other hand, the other date (H-2123/1538: $3745 \pm 60 \mathrm{BP}$; a fascine from construction of barrow was dated) relates to a very late phase of the CWC. None of those dates conforms with the interpretation, prevailing among German researchers (from U Fischer onwards), who would date the Mansfeld group to the second half of the 3rd millennium BC and link it with the beginnings of the development of local groups of the CWC.

On the basis of the 2 examples above, it can be concluded that it is risky to suggest a chronological model with all of the dates taken into consideration. Here, we can clearly see how archaeologists are striving to achieve a greater precision than that allowed for by the dating method. Another illustration of this is a comparison of a series of human bone dates from different laboratories. The examples are from Little Poland and Taubertal in Baden-Würtemberg. The first example (Figure 5) comprises a series done for the phase of the CWC catacomb graves in the Kiev and Poznan laboratories: 20 and 11 dates, respectively (Włodarczak 2001; Jarosz and Włodarczak 2007). Generally, there is a conformity in the results. However, in the first of the 2 series, there occurs a group of slightly older dates. Due to this slight difference, however, the older dates "fall" into a separate window made by the levelling out of the calibration curve. As a result, it is possible to suggest an archaeological interpretation according to which the horizon of the catacomb graves occurs very early in the CWC. This would be contrary to the previous results achieved on the basis of comparative typological analysis. A similar example is the situation from Taubertal in Baden-Württemberg (Figure 6; Dresely 2004). The dates performed in the Heidelberg laboratory for the Tauberbischofsheim-Dittigheim cemetery comply with the former assumptions: The site relates to the younger phase in the development of the CWC in Switzerland. Meanwhile, for the adjacent cemetery in Tauberbischofsheim-Impfingen, where typologically similar material was found, in the laboratory in Köln surprisingly young dates were obtained. They indicated that the style, typical for the CWC, existed as late as the turn of the 3rd and 2nd millennium BC. Due to the fact that these series of dates come from 2 different cemeteries, we cannot with complete certainty exclude the possibility that there is, in fact, a considerable difference in age between the 2 sites. However, taking into consideration the noticeable regularity in the age difference, this situation seems puzzling.

The above results are verifiable on the basis of the most recent series for CWC graves from southern Germany, performed in the laboratory in Kiel (Seregély 2008:179-98). For a large cemetery in 


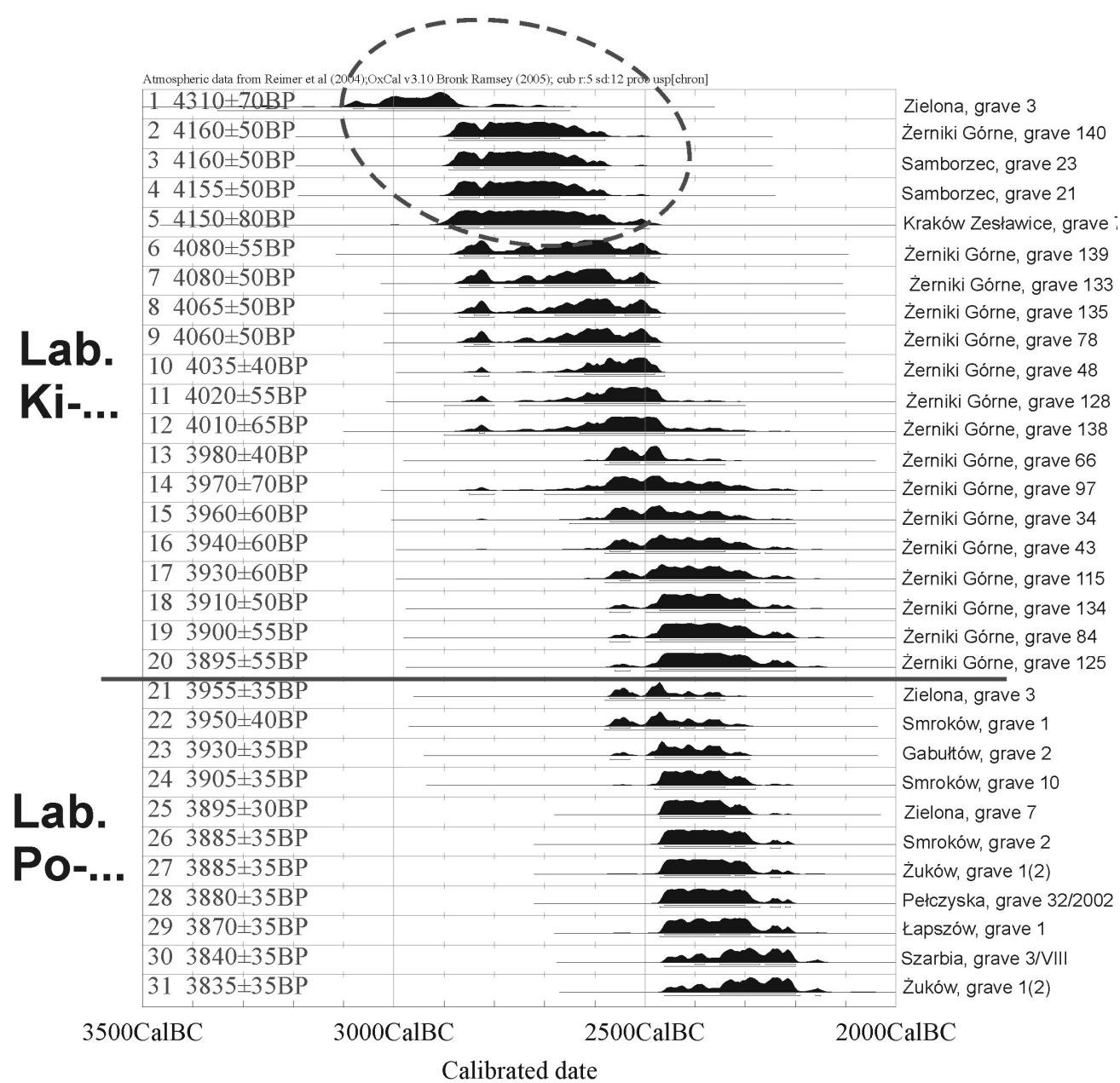

Figure $5{ }^{14} \mathrm{C}$ dates of the Corded Ware culture from Little Poland upland. The oldest problematic results are circled.

Lauda-Königshofen, also located in Taubertal, a series of 4 dates similar to those from Taubbischohsheim-Dittigheim was obtained (Seregély 2008:189, Abb. 152). In this case, the results did not show any exceptionally late chronological position of the materials from southwestern Germany. However, there are several single late dating results obtained for other sites (e.g. Kösching, KIA28813: $3440 \pm 39$ BC). According to Seregély (2008:198), this is caused by contamination of the materials, leading to rejuvenation of the age of the dated bones. In the proposed chronological scheme, the difficult-to-accept results are not taken into consideration (Seregély 2008:189, Abb. 170). Thus, the time period for CWC development was considerably reduced.

On the other hand, the differences between the results from particular laboratories are not so easy to notice in the case of the samples from central Germany (Müller 1999a,b). The relatively long series from the laboratories in Kiel and Köln (22 and 10 dates, respectively) yielded similar results for the CWC decline: With the greatest degree of probability, it can be dated to 2200-2000 BC. In the case of the first of the above series, there is a distinctive group of 5 older dates, linking the age of the graves to 2880-2580 BC, without a corresponding group in the other series of dates. Here, it must be emphasized that the dates from the laboratory in Köln—like in the case of Taubertal—show a rel- 


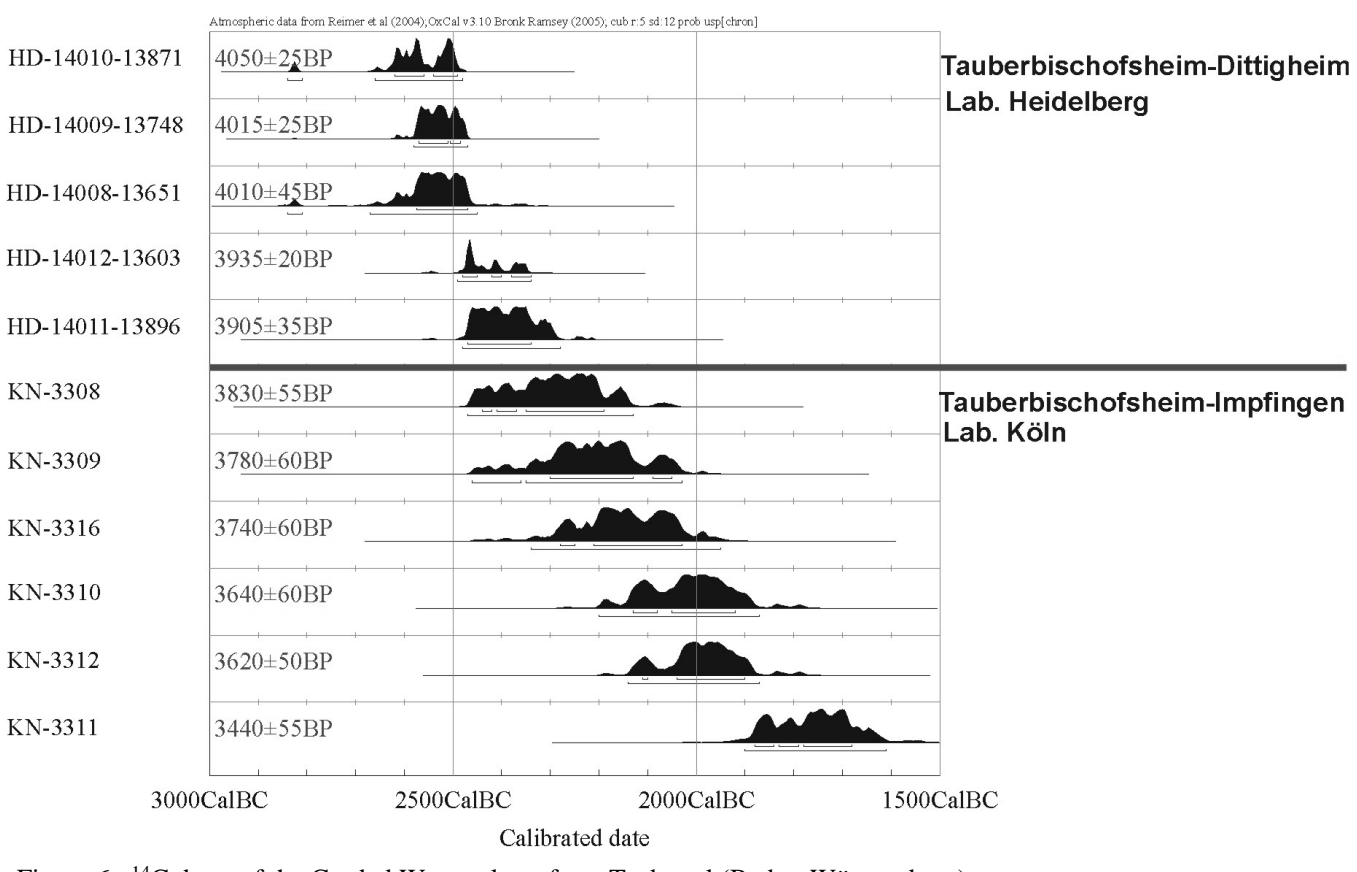

Figure $6{ }^{14} \mathrm{C}$ dates of the Corded Ware culture from Taubertal (Baden-Württemberg)

atively late age of some of the CWC graves. In the case of central Germany, this time range is also confirmed by the results from the laboratory in Kiel. Since the archaeological analysis of these results is problematic (it is difficult to accept a date of CWC materials to the Early Bronze period), another dating of these assemblages would provide a valuable clue for further archaeological study.

An analysis of all the ${ }^{14} \mathrm{C}$ dates shows that they mostly correspond, or most probably could correspond, to the CWC chronology in Switzerland as determined by dendrochronology. In this comparison, we notice different conditions of the CWC beginnings and of its decline. As far as the oldest dates are concerned, in particular regions there are only individual dates, which are regarded-with a great degree of probability - as older than $\sim 2750 \mathrm{BC}$. In other words, they are older than the beginnings of the CWC in Switzerland. In the case of the decline of the CWC, on the other hand, the situation is more difficult. Clearly, there are many CWC samples that are younger than $\sim 2400 \mathrm{BC}$, originating from various regions, and particularly from central and southern Germany. For the end of the CWC, we can talk about a systematically younger chronology of the youngest phase of the local CWC groups than the chronology of the CWC decline in Switzerland. In archaeological practice, this allows for frequent reconstructions, on the assumption of the coexistence of the CWC and Bell Beaker culture. However, in the light of the problems concerning the relations between individual dates, and series of dates from particular laboratories, this situation does not appear to be very clear and needs further verification.

Comparing the CWC materials, which would allow us to employ dendrochronological dates from Switzerland, attempting to determine the chronology of materials from southern Germany is not easy due to the difference in the stylistic characteristics of the finds. The recently published work by Ullrich (2008:74-9), in which correspondence analysis is used, illustrates this difficulty. Stylistic group "SK c," which is the key group for the CWC chronology from southwestern Germany and which includes the beakers typical of the territory between the rivers of Men, Neckar, and Rhine 
(described, among others, by E Sangmeister and V Heyd), does not have any analogy to the palafitte sites in the region of Zurich and on Lake Constance (Ullrich 2008:79). It is only possible to generally confront the stylistic groups "SK a" and "SK b," which are synchronized by Ullrich with the whole development period of the CWC from Switzerland. Meanwhile, the data from the sites on the lakes do not imply any date of the CWC decline in the river basin of the middle and upper Rhine. Currently, the question of the CWC sites dating to after 2400 BC can only be discussed on the basis of the ${ }^{14} \mathrm{C}$ dates.

Finally, as the last example in this paper, I would like to discuss the comparison between ${ }^{14} \mathrm{C}$ and dendrochronological dates from Switzerland. Figures 7 and 8 show ${ }^{14} \mathrm{C}$ dates from the Seefeld complex in Zurich and from the whole territory of Switzerland. In both cases, if we try to interpret ${ }^{14} \mathrm{C}$ dates for these areas in the same way as for other territories of Europe, we will not be able to show the time period established via dendrochronology. It will also be difficult to propose temporal relationships between materials of the CWC, Horgen, and Bell Beaker cultures, if reconstructed by ${ }^{14} \mathrm{C}$ dating.

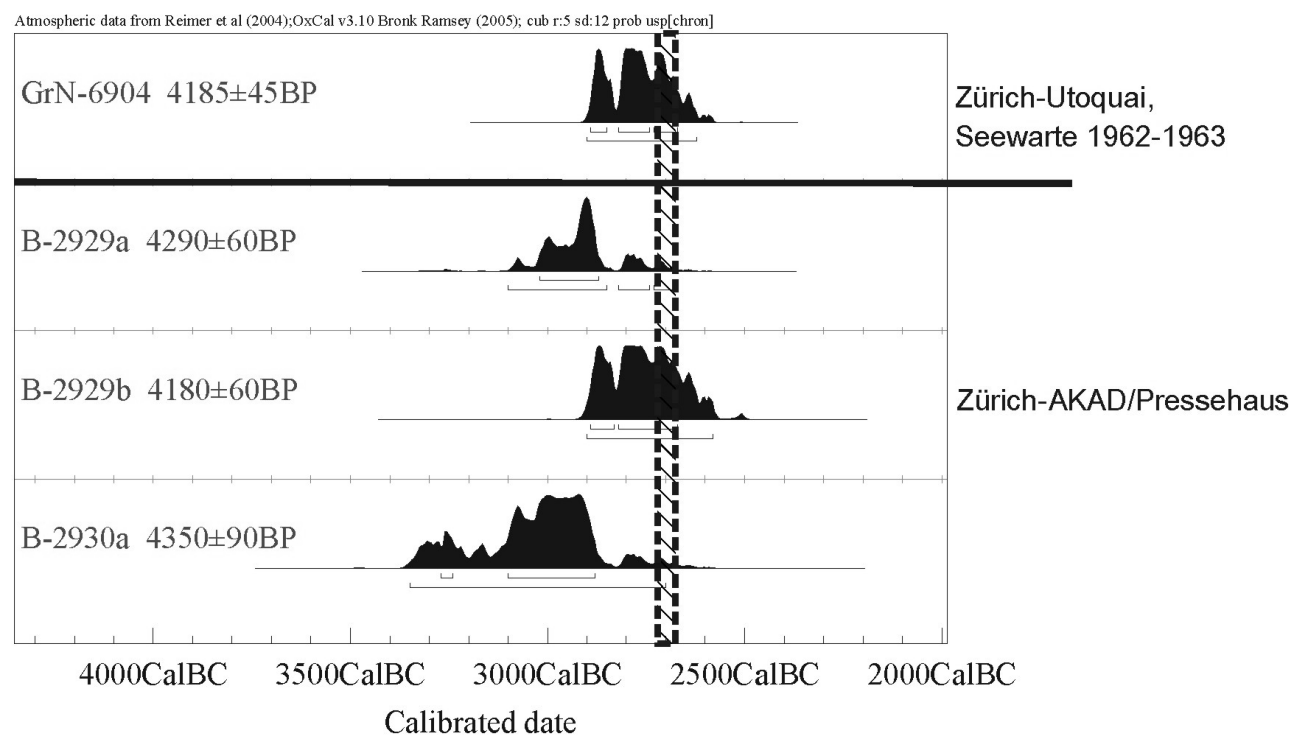

- dendrochronological dates from Zürich-Kanalisationssanierung (layers E-A)

Figure 7 Comparison of ${ }^{14} \mathrm{C}$ and dendrochronological dates of Corded Ware settlements from the Seefeld complex in Zurich

\section{CONCLUSIONS}

Due to the difficulties in correlating ${ }^{14} \mathrm{C}$ dates, and in using them to build chronological models, we should take a territory dated via dendrochronology as a point of reference. For ${ }^{14} \mathrm{C}$ dating, there is clearly the problem of hundreds of dates from different laboratories and performed in different years. A slight difference in the results leads to an "elongated" chronology and mechanical acceptance of the model of synchronicity of many cultural groups. Such a lack of precision, which can often be explained with statistics, is imposed on some objective difficulties, in the form of, for example, the characteristics of the calibration curve itself. In this situation, it is difficult to believe that a model satisfying an archaeologist could be constructed only on the basis of the dates yielded 


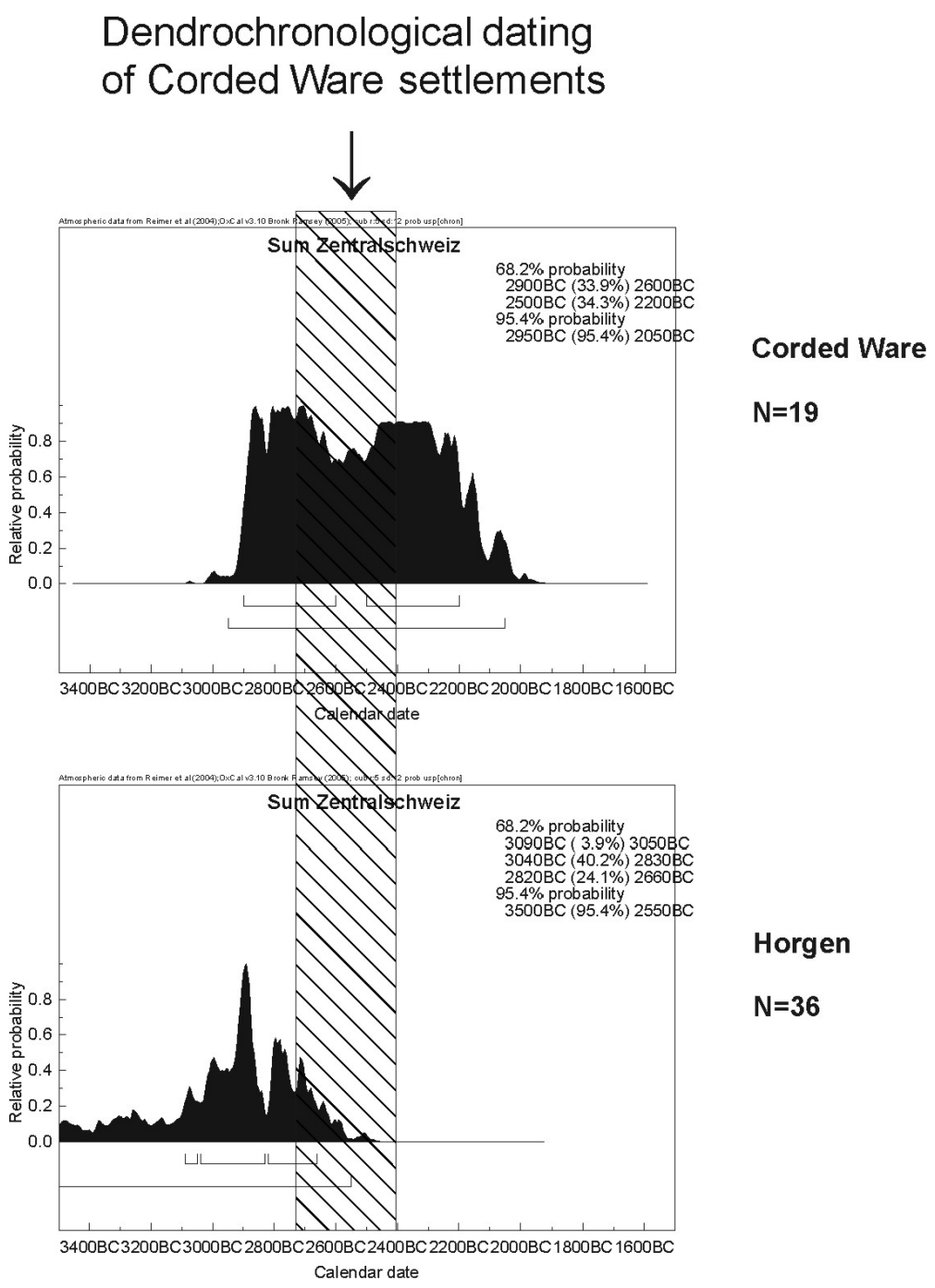

Figure $8{ }^{14} \mathrm{C}$ dating (summarized dates) and dendrochronology of the Corded Ware and Horgen cultures in Switzerland.

by the ${ }^{14} \mathrm{C}$ method. In the face of these problems, an archaeologist must treat ${ }^{14} \mathrm{C}$ dates like any other archaeological source, and evaluate them subjectively and critically. This has, obviously, nothing to do with the legitimacy of this method as such, but only with the way it ought to be employed.

The above-quoted examples show that there is a necessity for a discussion between archaeologists and those responsible for performing ${ }^{14} \mathrm{C}$ dates, which would lead towards verification and explanation of any arising controversies. These problems do not result from misunderstanding of the calibration methods by archaeologists (many of whom are proficient users of calibration and dating interpretation software). Far more important and difficult is the problem of how to establish an appropriate approach so that reliable and valid results are achieved. In archaeology, this problem is obvious in the case of estimations of the age of human bones in burials, a good example of which are the series of the CWC dates discussed in this paper. 


\section{REFERENCES}

Bleuer E, Gerber Y, Haenicke C, Hardmeyer B, Joos M, Rast-Eicher A, Ritzmann C, Schibler J. 1993. Jungsteinzeitliche Ufersiedlungen im Zürcher Seefeld. Ausgrabungen Kanalisationssanierung 1986-1988 (Zürich Kan. San. Seefeld). Volume 2: Tafeln. Zürich: Zürcher Denkmalpflege Archäologische Monographien 23.

Breunig P. 1987. ${ }^{14} \mathrm{C}$-Chronologie des vorderasiatischen, südost- und mitteleuropäischen Neolithikums. Fundamenta. Reihe A, Band 13, Köln.

Czebreszuk J. 1996. Spoteczności Kujaw w poczatkach epoki brazu. Poznań.

Czebreszuk J, Szmyt M. 2001. The 3rd millennium B.C. in Kujawy in the light of ${ }^{14} \mathrm{C}$ dates. In: Czebreszuk J, Müller J, editors. The Absolute Chronology in Central Europe During the 3rd Millennium B.C. Poznań-Bamberg-Rahden/Westf. p 177-208.

de Capitani A. 1993. Zürich-Bad Wollishofen-Untersuchungen 1991. Jahrbuch der Schweizerischen Gesselschaft für Ur- und Frühgeschichte 76:153-5.

Dresely V. 2004. Schnurkeramik und Schnurkeramiker im Taubertal. Forschungen und Berichte zur Vor- und Frühgeschichte in Baden-Württemberg 81. Stuttgart.

Eberschweiler B. 1999. Das jüngsten endneolitischen Ufersiedlungen am Zürichsee. Jahrbuch der Schweizerischen Gesselschaft für Ur- und Frühgeschichte 82: 29-64.

Furholt M. 2003. Die absolutchronologische Datierung der Schnurkeramik in Mitteleuropa und Südskandinavien. Bonn: Universitätsforschungen zur Prähistorischen Archäologie 101.

Furholt M. 2004. Entstehungsprozesse der Schnurkeramik und das Konzept eines Einheitshorizontes. Archäologisches Korrespondenzblatt 34(4):479-98.

Gerber Y, Haenicke C, Hardmeyer B. 1994. Jungsteinzeitliche Ufersiedlungen im Zürcher Seefeld. Ausgrabungen Kanalisationssanierung 1986-1988 (Zürich Kan. San.). Volume 2: Die Keramik. Zürich: Zürcher Denkmalpflege Archäologische Monographien 22.

Gross E, Brombacher C, Dick M, Diggelman K, Hardmeyer B, Jagher R, Ritzman C, Ruckstuhl B, Ruoff U, Schibler J, Vaughan PC, Wyprächtiger K. 1987. Zürich "Mozartstrasse". Neolitische und bronzezeitliche Ufersiedlungen. Volume 1. Zürich: Berichte der Zürcher Denkmalpflege, Monographien 4.

Gross-Klee E, Eberli U. 1997. Die archäologischen Grundlagen. In: Schibler J, Hüster-Plogmann H, Jacomet S, Brombacher C, Gross-Klee E, Rast-Eicher A. 1997. Ökonomie und Ökologie neolitischer und bronzezeitlicher Ufersiedlungen am Zürichsee. Zürich: Monographien der Kantonsarchäologie Zürich 20. p 18-37.

Hardmeyer B. 1993. Die Schnurkeramik, In Bleuer E. Hardmeyer B. Zürich "Mozartstrasse". Neolitische und bronzezeitliche Ufersiedlungen. Volume 3: Die neolitische Keramik. Zürich: Zürcher Denkmalpflege Archäologische Monographien 18. p 292-340.

Hardmeyer B, Ruoff U. 1983. Die Tauchausgrabung in Zürich-Bad-Wollishofen. Jahrbuch der Schweizerischen Gesselschaft für Ur- und Frühgeschichte 66: $17-42$.

Hübner E. 2005. Jungneolithische Gräber auf der Jütischen Halbinsel. Typologische und chronologische Studien zur Einzelgrabkultur. København.

Jarosz P, Włodarczak P. 2007. Chronologia bezwzględna kultury ceramiki sznurowej w Polsce południowowschodniej oraz na Ukrainie. Przeglad Archeologiczny 55:71-108.

Kośko A. 1992. Z badań nad tzw. horyzontem starosznurowym w rozwoju późnoneolitycznej kultury społeczeństw Kujaw. Acta Universitatis Lodziensis, Folia Archaeologica 16:85-95.

Lanting JN, van der Plicht J. 1999/2000. De ${ }^{14}$ C-chronologie van de Nederlandse pre- en protohistorie, III: Neolithicum. Palaeohistoria 41/42:1-110.

Lanting JN, van der Waals JD. 1976. Beaker Culture relations in the Lower Rhine Basin. In: Lanting JN, van der Waals JD, editors. Glockenbecher Symposium. Oberried. p 1-80.

Michel R. 2002. Typologie et chronologie de la céramique néolithique. Saint-Blaise/Bains des Dames. Volume 3. Neuchâtel: Archéologie neuchâteloise 27.

Müller J. 1999a. Zur Radiokarbondatierung des Jung- bis Endneolithikums und der Frühbronzezeit im Mittelelbe-Saale Gebiet (4100-1500 v. Chr.). Bericht der Römisch-Germanischen Komission 80. p 31-90.

Müller J. 1999b. Zur absoluten Chronologie der mitteldeutschen Schnurkeramik. Erste Ergebnisse eines Datierungsprojektes. Archäologisches Nachrichtenblätter 4/1:76-88.

Peschel K. 1963. Ein Grabhügel mit Schnurkeramik von Dornburg, Landkreis Jena. A. Ausgrabung und Befund. Praehistorische Zeitschrift 41:83-133.

Raetzel-Fabian D. 2000. Calden. Erdwerk und Bestattungsplätze des Jungneolithikums. Architektur-Ritual-Chronologie. Bonn: Universitätsforschungen zur Prähistorischen Archäologie 70.

Ramseyer D. 1988. La céramique néolithique d'Auvernier-La Saunerie (fouilles 1964-1965). Lausanne: Cahiers d'Archéologie Romande 45.

Schibler J, Hüster-Plogmann H, Jacomet S, Brombacher C, Gross-Klee E, Rast-Eicher A. 1997. Ökonomie und Ökologie neolitischer und bronzezeitlicher Ufersiedlungen am Zürichsee. Zürich: Monographien der Kantonsarchäologie Zürich 20.

Schlichtherle H. 1991. Taucharchäologische Untersuchungen in der Ufersiedlung Ludwigshafen-Seehalde, Gemeinde Bodman-Ludwigshafen, Kreis Konstanz. Archäologische Ausgrabungen in Baden-Württemberg 1991. Stuttgart. p 65-9. 
Seregély T. 2008. Endneolitische Siedlungsstrukturen in Oberfranken I. Wattendorf-Motzenstein: eine schnurkeramische Siedlung auf der Nördlichen Frankenalb. Studien zum dritten vorchristlichen Jahrtausend in Nordostbayern. Bonn: Universitätsforschungen zur prähistorischen Archäologie 154.

Strahm C. 1971. Die Gliederung der schnurkeramischen Kultur in der Schweiz. Bern: Acta Bernensia 6.

Strahm C. 1992. Die Dynamik der schnurkeramischen Entwicklung in der Schweiz und in Südwestdeutschland. In: Buchvaldek M, Strahm C, editors. Die kontinentaleuropäischen Gruppen der Kultur mit Schnurkeramik. Schnurkeramik-Symposium PrahaStirin 1990. Praehistorica 19. Praha. p 163-77.

Ullrich M. 2008. Endneolitische Siedlungskeramik aus Ergersheim, Mittelfranken. Untersuchungen zur Chronologie von Schnurkeramik- und Glockenbechern an Rhein, Main und Neckar. Bonn: Universitätsforschungen zur prähistorischen Archäologie 160.

van der Plicht J, Shishlina N, Hedges REM, Zazovskaya EP, Sevastianov VS, Chichagova OA. 2006. Reservoir effect and ${ }^{14} \mathrm{C}$-chronology of the Catacomb cultures of the North-West Caspian Steppe area: a case study. Eurasia Antiqua 12:113-26.

Winiger J. 1993. Dendrodatierte Schnurkeramik der Schweiz. Praehistorica 20. Praha. p 9-118.

Włodarczak P. 2001. The absolute chronology of the Corded Ware Culture in the south-eastern Poland. In: Czebreszuk J, Müller J, editors. The Absolute Chronology in Central Europe During the 3rd Millennium B.C. Poznań-Bamberg-Rahden/Westf p 103-29.

Włodarczak P. 2004. Cemetery of Corded Ware culture in Zielona, Koniusza commune, Małopolska. Sprawozdania Archeologiczne 56:307-60.

Włodarczak P. 2007. Problem chronologii radioweglowej kultury ceramiki sznurowej w świetle dendrochronologicznych datowań późnoneolitycznych osad palafitowych ze Szwajcarii. Archeologia Polski 52(1-2):35-80.

Wolf C. 1993. Die Seeufersiedlung Yverdon, Avenue des Sports (Kanton Waadt). Eine kulturgeschichtliche und chronologische Studie zum Endneolithikum der Westschweiz und angrenzender Gebiete. Lausanne: Cahiers d'Archéologie Romande 59. 